\title{
Job losses and political acceptability of climate policies: why the 'job-killing' argument is so persistent and how to overturn it
}

\author{
Francesco Vona (iD ${ }^{a, b, c}$

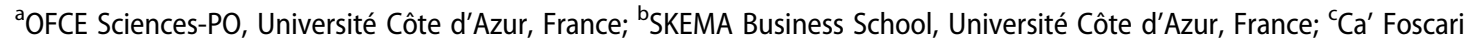 \\ University, Valbonne, Italy
}

\begin{abstract}
Political acceptability is an essential issue in choosing appropriate climate policies. Sociologists and behavioural scientists recognize the importance of selecting environmental policies that have broad political support, while economists tend to compare different instruments first on the basis of their efficiency, and then by assessing their distributional impacts and thus their political acceptability. This paper examines case-study and empirical evidence that the job losses ascribed (correctly or incorrectly) to climate policies have substantial impacts on the willingness of affected workers to support these policies. In aggregate, the costs of these losses are significantly smaller than the benefits, both in terms of health and, probably, of labour market outcomes, but the losses are concentrated in specific areas, sectors and social groups that have been hit hard by the great recession and international competition. Localized contextual effects, such as peer group pressure, and politico-economic factors, such as weakened unions and tightened government budgets, amplify the strength and the persistence of the 'job-killing' argument. Compensating for the effects of climate policies on 'left-behind' workers appears to be the key priority to increase the political acceptability of such policies, but the design of compensatory policies poses serious challenges.
\end{abstract}

\section{Key policy insights}

- Public perception of, and support for, climate policies is substantially reduced in the presence of large negative shocks, especially job losses.

- Climate policies can be perceived as negative for employment, especially in areas where polluting industries represent a large share of employment and in occupations and sectors already damaged by globalization and automation.

- Policymakers should distinguish between small and large distributional effects of climate policies, and find the appropriate combination of revenue recycling schemes, industrial and retraining policies as well as compensation packages to increase the support for such policies.

\section{ARTICLE HISTORY}

Received 15 March 2018

Accepted 2 October 2018

\section{KEYWORDS}

Climate policies; employment impacts; distributional impacts; collective action problems; amplification mechanisms; political acceptability

\section{Introduction}

Claiming that regulation will lead to job losses is a compelling argument put forward by energy-intensive industries to undermine the political acceptability of unilateral climate policies (e.g. Coglianese, Finkel, \& Carrigan, 2014; Morgenstern, Pizer, \& Shih, 2002). The exit of the US from the Paris Agreement is just the most recent symptom of a political choice justified by the need to defend the jobs of coal miners and blue-collar workers in energy-intensive sectors. Concern for job losses resonates also in the text of the Paris Agreement, which explicitly mentions, in its preamble, the need for a 'just transition of the workforce', presumably referring to workers displaced by climate policies in polluting industries. 
This attention towards job losses may appear excessive at first glance, given widespread agreement that the aggregate welfare benefits of environmental policies largely exceed the costs of job losses for exposed industries and occupations (e.g. Smith, 2015). Computable general equilibrium, post-Keynesian and input-output models all show that the jobs destroyed in energy-intensive industries are likely to be offset (or more than offset) by new well-paid jobs in green industries, such as renewable energy, building retrofitting, waste management and pollution abatement (Barker, Alexandri, Mercure, Ogawa, \& Pollitt, 2016; Hafstead \& Williams, 2018; Pollitt, Alexandri, Chewpreecha, \& Klaassen, 2015; Wei, Patadia, \& Kammen, 2010). A successful relocation from 'brown' to 'green' jobs can, however, be particularly difficult given the potentially large differences in their skill requirements (Vona, Marin, Consoli, \& Popp, 2018a). Walker (2013) finds that the permanent earnings losses for workers displaced by the US Clean Air Act can be very large, especially for those who change industries. Taken together, this evidence suggests that, although the aggregate effect of climate policies is unquestionably positive in terms of health and probably neutral in terms of employment, losses for displaced workers in polluting industries can be large.

This policy analysis discusses the extent to which extreme distributional effects, either in terms of long-term unemployed or permanent earnings losses, may undermine the political acceptability of climate policies, even in the presence of negligible aggregate employment and competitiveness effects (Dechezleprêtre \& Sato, 2017). In light of solid empirical evidence showing that a unilateral climate policy costs jobs in polluting industries (e.g. Greenstone, 2002; Walker, 2011) and induces a relocation of economic activities toward regions (within a country) and countries (globally) with laxer environmental policies (Kahn \& Mansur, 2013; Mulatu, Gerlagh, Rigby, \& Wossink, 2010), costs and benefits of such policies are unevenly distributed. A large majority of modest winners coexists with a tiny fraction of big losers, basically those that lose their job in polluting industries. That is, we are in the presence of a classic collective action problem because agents that are modestly winning are unlikely to get organized to support climate policies, while the losers have everything at stake if the policy is approved. While collective action theory (Olson, 1965) is the natural starting point to analyse the political consequences of extreme distributional effects, this paper discusses a number of amplifying factors that can fuel widespread discontent against climate policies, especially in regions that are hit hard by other shocks (e.g. globalization) and appear to be abandoned by central governments facing increasingly tight budget constraints. The paper also discusses the effectiveness of policy solutions including retraining, worker compensation packages and active green policies, as well as the general issue of whether combatting climate change can be effective in a world with an increasing fraction of people 'left behind' in wealthy societies.

\section{Green preferences vs. jobs and earnings}

This paper discusses under what circumstances a conflict between green preferences and economic goals, such as jobs and earnings, can emerge. As starting point, it is useful to think of individuals as socio-economic actors that play multiple roles associated with multiple types of interactions with the natural environment. In particular, they are consumers and workers as well as, under certain conditions, voters, and 'green' or 'brown' political activists. Their environmentally-related choices in each of these roles are obviously driven by the complex interplay of both economic and non-economic (mostly behavioural and cultural) factors, provided that individuals are bounded rational actors embedded in a social context and endowed with inherited beliefs.

Among the main socio-cultural and behavioural drivers, which are discussed extensively elsewhere (e.g. Lee, Markowitz, Howe, Ko, \& Leiserowitz, 2015), intrinsic values (e.g. ethical considerations, intergenerational equity), inaccurate perceptions of health impacts and behavioural inertia contribute to explaining, for instance, the energy efficiency gap, i.e. the unexploited win-win opportunities to reduce energy consumption without decreasing individual welfare (Allcott and Greenstone, 2012). Contextual factors, such as social norms, information diffusion and peer effects, are also very important in influencing the political acceptability of climate policies (Carattini, Baranzini, Thalmann, Varone, \& Vöhringer, 2017; Drews \& Van den Bergh, 2016). Recent research has shown that imitation effects, namely the natural human propensity to replicate the behaviour of friends and neighbourhoods, increased the political acceptability of both feed-in tariffs and solar rooftop PV panels in Germany and California (Bollinger \& Gillingham, 2012; Comin \& Rode, 2013; Rode \& Weber, 2016), while 
social comparisons are found to affect the adoption of energy-efficient behaviours or mitigation practices (Allcott, 2011; Biel \& Thøgersen, 2007).

Economic drivers of green preferences can be conveniently classified depending on their size and concentration. As consumers, individuals are affected by climate policies that alter the relative prices of goods with different carbon intensities. Empirical evidence on the environmental Kuznets curve shows that green preferences emerge once basic needs are satisfied, revealing that green preferences are lower in the priority scale (Dinda, 2004; Vona \& Patriarca, 2011). Unless the health effects of climate change are easily understandable, verifiable and perceived to be large, poorer households are unlikely to be willing to support policies that, at least in the medium-term, increase the cost of energy inputs. Notice that, because it is more likely that poorer households are less educated, they may have limited knowledge of the health effects of climate change, thus amplifying the effect of wealth on green preferences. On the other hand, however, it is also less likely that small distributional impacts, such as those associated with changes in the relative prices of 'brown' and 'green' goods, will emerge into clear opposition to climate policies. Indeed, environmental policies represent a secondary component of a broader political package and are bundled together with other policies that may or may not favour poorer households. For instance, a political party that proposes a carbon tax and an increase in tax progressivity can be voted for by less-advantaged households on the basis of the small distributional effects of the climate policy. Because of policies' bundling, small distributional effects become almost irrelevant for the political acceptability of climate policies compared to socio-cultural and behavioural factors and large distributional effects, notably job losses.

To quantify potential large losers of on-going and planned climate policies, Figure 1 plots the evolution in the share of workers exposed to climate policies over the total workforce in selected countries divided into four groups (i.e. Western Europe, Eastern Europe, BRICS ${ }^{1}$, non-EU OECD countries). The exposed workers are defined as (see the caption in Figure 1 for details): (i) working in a polluting industry; and (ii) having low or medium educational attainments. Indeed, unskilled workers including high-school graduates are also exposed to other negative shocks such as automation and trade (Acemoglu \& Autor, 2011; Autor, Dorn,
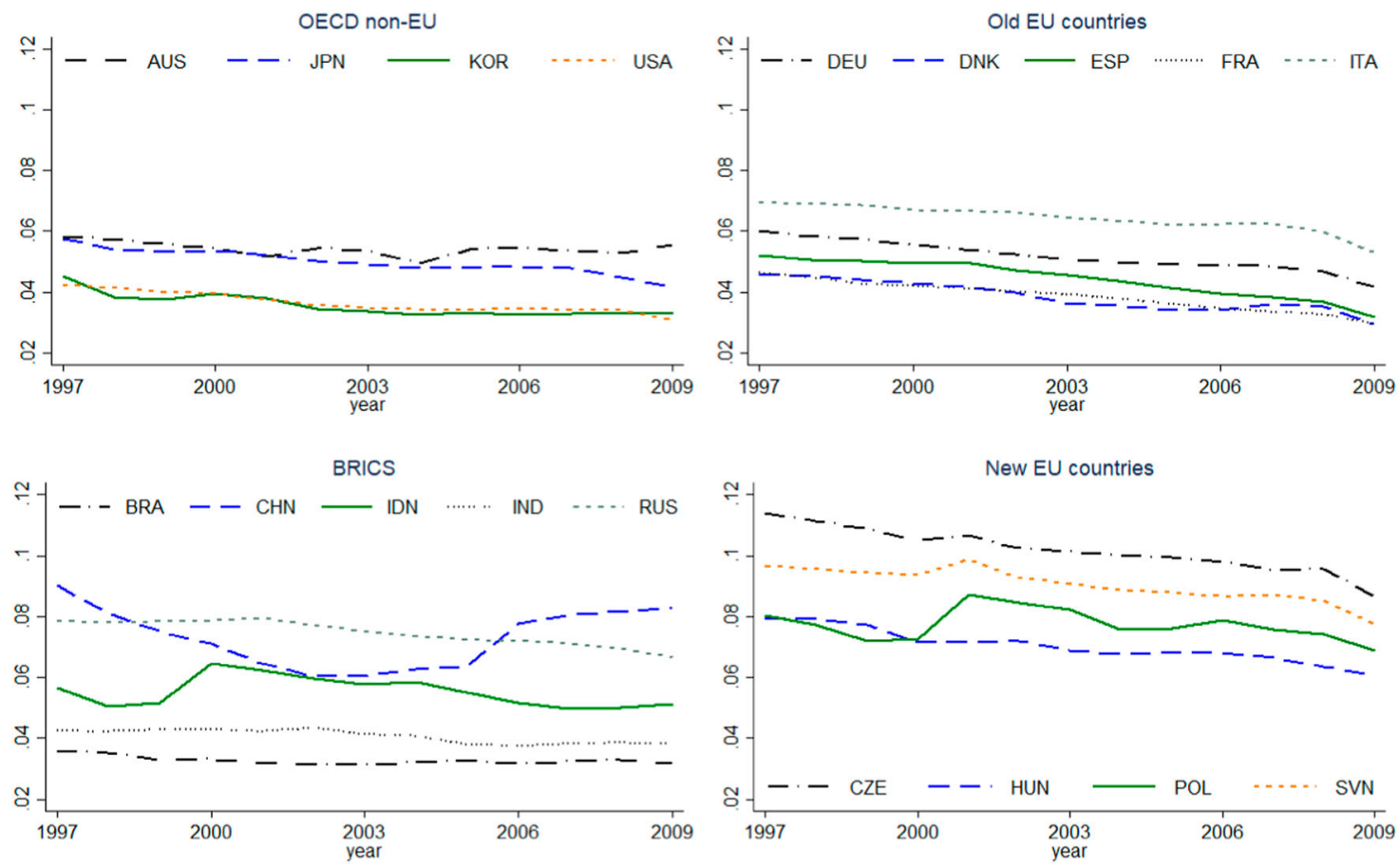

Figure 1. Evolution of vulnerable workers in highly polluting industries share of hours worked on total hours. 
Hanson, \& Song, 2014) and thus, after losing their jobs in a polluting industry, are unlikely to find an equivalent job in terms of pay, career development and occupational prestige. ${ }^{2}$ The most likely outcome is to be reemployed in a low-skilled service job at the bottom end of the wage distribution. The Figure shows the fraction of affected workers declining over time and almost everywhere, but it is still in the range between $2.9 \%$ and $3.1 \%$ (in Demark, France, Brazil and the US) and 8.2-8.6\% (in Czech Republic and China). A recent study by Marin and Vona (2018) finds that the decline of employment in EU polluting industries occurred before the implementation of environmental regulations, thus it is most likely to be a result of globalization and automation. However, this study also finds that environmental policies reduced the employment share of blue-collar workers. Overall, the increased vulnerability of 'left-behind' workers distorts their perception regarding the impact of environmental policies on jobs, and lays a fertile ground for the 'job-killing' argument, cementing an unlikely alliance between unions and industrial lobbies.

\section{The political consequences of job losses: case studies}

In this section, the paper explores how the 'job-killing' argument and the associated collective action problem translate into a 'chilling effect' on the stringency of climate policies, namely the setting of an environmental regulation less stringent than the social optimum, which goes beyond the expected and well-documented reactions of brown industrial lobbies. First, the 2008 global recession can be seen as a 'natural experiment' in how priorities change in the presence of destructive economic shocks. In the US, Kahn and Kotchen (2011) showed that an increase in state unemployment rates decreased the incidence of Google internet searches for 'global warming', a proxy of public concern for climate change, and increased those for 'unemployment', especially so in Republican states. Scruggs and Benegal (2012) used a panel of public opinion surveys in the US and EU to show that concern for climate change dramatically declined after the 2008 recession. Clearly, the great recession represented a sharp discontinuity in the way people rank priorities. In normal times socio-cultural and behavioural drivers are extremely important, if not more important, than economic factors; conversely, in the presence of large negative income shocks, people's concerns for jobs dominate over their concerns for climate change.

The second evidence on the politico-economic consequences of job and competitiveness losses can be found in the widespread policy exemptions and laxer regulation enjoyed by polluting industries that should be the target of such policies, both in Europe and in the US (Ekins \& Speck, 1999; Martin, Muûls, De Preux, \& Wagner, 2014; Stavins, 2003; Ward \& Cao, 2012). With regard to the EU-Emission Trading Scheme (EU-ETS), for instance, research shows that the risk of industrial relocation is not enough to justify the free allocation of emissions permits and generous policy exemptions for trade-exposed, energy-intensive sectors (Joltreau \& Sommerfeld, 2018; Martin et al., 2014). ${ }^{3}$ Not only brown industrial lobbies used the 'job-killing' argument to contrast climate policies ensuring generous exemptions to polluting industries, but concerns about the risk of job losses in specific industries have been also expressed by institutional actors, unions and local communities. One of the most echoed cases in the media has been that of the giant steel factory of Taranto (Southern Italy), the so-called ILVA, which over time has caused sizeable health damages to the local population (The Economist, 2012). Although the ILVA repeatedly violated environmental and health regulations, in 2012, the Italian government passed a decree that allowed it to continue production without a credible engagement to reduce emissions. In 2013, the decree was declared legitimate by the Italian constitutional court on basis of the absolute necessity to preserve jobs in a region hit hard by the 2008 crisis (Pascucci, 2014).

There are other cases of exemptions from environmental regulations justified by the risk of job losses and shared by unions and local communities (Galgóczi, 2014). In France, unions played a key role in postponing the shutdown of five coal power plants (Le Monde, 2018), while in Poland, coal is still subsidized (Caldecott, Sartor, \& Spencer, 2017) and, in Sweden, polluting industries pay a reduced carbon tax (OECD, 2014). ${ }^{4}$ These cases suggest that the chilling of environmental regulation also depends on the public acceptability of climate policies in areas where both costs and benefits are concentrated. In Dunkirk (France), where large steel and petrochemical firms are located, Le Blanc and Zwarterook (2014) show that health risks are not seen as a priority by the local population and that economic development and defending jobs are instead recognized as the key priorities. 
What clearly emerges from these cases is that job creation has a priority over health also for the same people whose health is most affected by polluting activities. Moreover, the geographical concentration of job losses may strongly undermine the political acceptability of climate policies.

However, with the exception of Cragg, Zhou, Gurney, and Kahn (2013) for the US, there is still scant direct evidence of the political choices of local communities that may be affected by climate policies in terms of job losses. In line with the findings of the above case studies, these authors show that US congressional representatives from carbon-intensive and poorer areas have a lower probability of voting in favour of legislation to regulate carbon. Taking stock of these findings, it seems that the perceived negative effect of regulation on jobs shapes the electors' preferences, especially in most vulnerable regions where job opportunities in other sectors are absent or unattractive. Although, to the author's knowledge, there is no evidence for other countries, an analogy can be made with trade liberalization. Autor, Dorn, Hanson, and Majlesi (2016) for the US, and Colantone and Stanig (2017) for EU countries, find that an increase in regional exposure to Chinese competition increases extreme right-wing and nationalistic positions. This result bears relevance for climate policies because manufacturing jobs disappeared not only in 'light' industries, such as textiles and apparel, but also in the dirtier segments of equipment manufacturing, metals and chemicals. Globalization is thus, not surprisingly, the key amplifier fuelling hostility against climate policies; the next section discusses this and other amplifiers in greater detail. ${ }^{5}$

\section{Amplifiers of the 'job-killing' argument}

The financial crisis and the increase of international competition from China are two fundamental factors that, by increasing pressure on local labour markets, may amplify the penetration of the 'job-killing' argument in affected communities. As mentioned in the previous section, a key related aspect is the spatial distribution of the impact of climate policies, which is likely to be highly concentrated as polluting industries tend to co-locate in the same area (e.g. steel and coal). As a result, regions hosting polluting industries may lack the required options for diversification to transform climate policies from a constraint into an opportunity. ${ }^{6}$ Not surprisingly, Rosés and Wolf (2018) show that regions with a higher proportion of energy-intensive industries and mining have been the main losers from European deindustrialization during the twentieth century.

Geographical concentration of losers can amplify political opposition against climate policies thorough the behavioural channels mentioned in Section 2. Indeed, the likelihood of interacting with a worker who has been negatively affected by globalization or environmental regulations is higher in disadvantaged communities. Because social interactions nourish political beliefs as well as consumer preferences, segregated societies will exacerbate collective action problems through peer effects. Group identity also acts as an amplifier insofar as, at least in the US, brown jobs tend to be dominated by white males-a group heavily exposed to trade shocks (Autor, Dorn, \& Hanson, 2017). Further research is required to understand the role of group identity and peer effects in amplifying the support for or against climate policies.

Several political factors contribute to amplifying the 'job-killing' discourse, besides those related to the persistence of political constituencies and lobbying. These factors range from the widespread weakening of unions and of workers' bargaining power, which has led to the quantity of jobs increasingly taking priority over their quality (including health and environmental conditions) in industrial relations ${ }^{7}-$ to capital mobility and the erosion of the tax base - which has tightened government budgets and reduced the generosity of compensation schemes. As the demand for social protection from most vulnerable citizens has increased, trade and environmental policies became the natural substitutes for social policies (Colantone \& Stanig, 2017). As a result, populistic political platforms, which are increasingly supported by former blue-collar workers, have bundled an anti-globalization discourse together with proposals to repeal 'job-killing' environmental regulations. However, because trade policies are difficult to overturn unilaterally (Nordhaus, 2015) ${ }^{8}$, environmental regulations are an easier target to satisfy the increased demand for protection, further amplifying the 'jobkilling' argument.

The distance between the skill requirements of brown and alternative jobs in the local labour market is another discriminant factor that, through the set of potential opportunities for displaced workers, affects the political acceptability of climate policies. In the Ruhr region in Germany, for instance, local competences in mining technologies were suitable for use in renewable energy production and recycling technologies. ${ }^{9}$ This 
may not be the case in regions with less efficient retraining facilities and weaker skill bases than the Ruhr. While coal mines in the Netherlands represent another example of successful labour market transition, in Poland, miners faced considerable difficulties to be reemployed in an equivalent job (Caldecott et al., 2017). ${ }^{10}$ It is not only skill gaps that are important, but also the average quality of the non-brown jobs available in the local economy. Recently, at least in the US, an element of concern has been that the average job quality has decreased with an increasing share of educated workers ending up in low-paid service sector jobs (Beaudry, Green, \& Sand, 2016).

Obviously, not all factors go in favour of the 'job-killing' political constituency. The main compensating factor is that climate policies also create winners, namely, firms and workers in emerging green sectors that can organize and combat the brown political constituency. However, there is a fundamental asymmetry between brown losers, who tend to be low-skilled individuals with few outside opportunities, and green winners, who, as shown by Vona et al. (2018a), seem to be mostly high-skilled workers with plenty of outside opportunities. The extent to which this asymmetry translates into a different degree of effective political participation and activism remains an open issue that requires further investigation. Other mitigating factors can be the result of clever policy choices that will be discussed in the concluding section.

\section{Conclusions}

The extreme forms of discontent created by climate policies are a gift to the true vested interests defending the status quo of lax carbon regulations: the companies in heavily polluting sectors. The 'job-killing' argument is just a weapon in the basket of brown lobbies, although, as argued in this paper, it is certainly one of the most important. A pragmatic approach to climate policy should consider, as a priority, implementing countervailing policies to minimize the collective action problem associated with extremely negative economic shocks.

A main issue for an effective design of these countervailing policies is whether subsidies should be channelled to displaced workers or to build comparative advantages in new sectors. If the choice is mainly to transfer money to displaced workers, the comparison of the cases of the Ruhr and of Netherland mines with that of Polish mines suggests that redundancy payments are very important but should not be exceedingly long, and should be combined with retraining policies. As a recent choice experiment survey has shown (Carattini et al., 2017), lump-sum transfers to affected workers and communities are probably the best way to increase the political acceptability of climate policies (see also Sverker, Martinsson, \& Matti, 2018).

If the choice is mainly to invest in other sectors that can absorb workers displaced from polluting ones, the revenues of a carbon tax can be used in two ways. First, they can finance industrial policies, including workers' retraining, in support of the green economy (Fankhauser, Sehlleier, \& Stern, 2008). However, this approach may not suffice if specialization in greener production is specific to certain locations, and thus difficult to transfer to areas lagging behind. The evidence in Vona, Marin, and Consoli (2018b) suggests that this is the case, as the areas creating more green jobs also tend to host high-tech industries and national research laboratories. Such persistence is not surprising because technological transitions take time, and are characterized by positive feedback loops from the implementation of a coherent set of climate and social policies that enhance support for such policies (Rosemberg, 2010).

An alternative plan, which has worked particularly well in Canada, is to recycle the revenues from a carbon tax to reduce labour taxation (e.g. Yamazaki, 2017). Although this tax reform may not prevent the relocation of polluting industries or parts of such industries elsewhere, reducing labour taxation enhances the incentives to create jobs in other sectors. The main disadvantage of this solution is that, without industrial policy to create a comparative advantage in green sectors and thus high-quality green jobs, the new jobs may be created in the low-skill segments of the service sectors where salaries are lower than in old jobs. As a result, the political discontent caused by climate policies will not be mitigated. Against this background, a more general issue is how to address the pronounced skill-biased effects of recent labour market transformations, which call for active redistributive policies both at the national and at the international level. Fighting climate change will be difficult in the years to come without a serious plan to reduce within-country inequality in the distribution of the fruits of economic growth. 


\section{Notes}

1. BRICS: Brazil, Russia, India, China and South Africa.

2. The effect of automation and of the diffusion of information and communication technologies in the workplace are clearly far larger than those of climate policies, as these technologies have potential applications in all sectors. In turn, climate policies directly affect production processes in a set of sectors that represent a significantly smaller share of total employment (basically manufacturing and energy) in nowadays developed economies.

3. This finding is consistent with that of the literature on the so-called pollution haven hypothesis, pointing to a modest effect of asymmetric environmental policies on foreign direct investment and industrial relocation (Dechezleprêtre \& Sato, 2017).

4. Similar evidence is available for emerging eastern European economies (Politico, 2016) and Australia (Mathys \& de Melo, 2011). In their congresses, both the International Transport workers' Federation (ITF) and the International Federation of Chemical, Energy, Mine and General Workers' Unions (ICEM) explicitly stated that climate policies should be implemented in such a way to protect jobs through a process of just transition (Rosemberg, 2010). Other interesting cases studies of distributional impacts and their political consequences are in Sovacool, Linnér, and Goodsite (2015).

5. Automation is less problematic as an amplifier of the "job killing" argument because it is not policy-driven. Technological choices of companies are not subject to regulation in the same way as the choice to export or to shift dirtier segments of production abroad.

6. The lack of industrial diversification is also a well-known determinant of the so-called natural resource curse associated with the exploitation of exhaustible resources (Van der Ploeg, 2011).

7. While the International Labour Organization plays a key role in promoting sustainable growth, we saw in Section 3 that weakened national unions rarely have the bargaining power to actively negotiate greener investment strategies with multinational and local firms.

8. Trade policies are nested in a more comprehensive and binding legal framework than climate policies.

9. Public sector investments and long-term planning promoting industry diversification and learning represent two related factors that ensured a successful transition in the Ruhr region (e.g., Taylor, 2015; Thimm, 2010).

10. Caldecott et al. (2017) report that $30-40 \%$ Polish coal miners were unemployed or out of the labour force two years after displacement

\section{Acknowledgements}

I thank David Popp for useful comments, and Marinella Davide and Will McDowall for useful suggestions.

\section{Disclosure statement}

No potential conflict of interest was reported by the author.

\section{Funding}

This work was supported by Horizon 2020 Framework Programme, project INNOPATHS [grant number 730403].

\section{Data Availability Statement}

The data that supports the findings of this study are publicly available in the following URL: Figure 1: Growth and Productivity Accounts, http://www.euklems.net/ The final datasets are also available from the corresponding author.

\section{ORCID}

Francesco Vona (iD) http://orcid.org/0000-0002-2112-5537

\section{References}

Acemoglu, D., \& Autor, D. (2011). Skills, tasks and technologies: Implications for employment and earnings. Handbook of Labor Economics, 4, 1043-1171.

Allcott, H. (2011). Social norms and energy conservation. Journal of Public Economics, 95(9), 1082-1095.

Allcott, H., \& Greenstone, M. (2012). Is there an energy efficiency gap? Journal of Economic Perspectives, 26(1), 3-28. 
Autor, D., Dorn, D., \& Hanson, G. (2017). When work disappears: Manufacturing decline and the falling marriage-market value of men, NBER Working Paper 23173.

Autor, D., Dorn, D., Hanson, G., \& Majlesi, K. (2016). Importing political polarization? NBER Working Paper 22637.

Autor, D., Dorn, D., Hanson, G., \& Song, J. (2014). Trade adjustment: Worker-level evidence. The Quarterly Journal of Economics, 129(4), 1799-1860.

Barker, T., Alexandri, E., Mercure, J.-F., Ogawa, Y., \& Pollitt, H. (2016). GDP and employment effects of policies to close the 2020 emissions gap. Climate Policy, 16(4), 393-414.

Beaudry, P., Green, D. A., \& Sand, B. M. (2016). The great reversal in the demand for skill and cognitive tasks. Journal of Labor Economics, 34(S1), S199-S247.

Biel, A., \& Thøgersen, J. (2007). Activation of social norms in social dilemmas: A review of the evidence and reflections on the implications for environmental behavior. Journal of Economic Psychology, 28(1), 93-112.

Bollinger, B., \& Gillingham, K. (2012). Peer effects in the diffusion of solar photovoltaic panels. Marketing Science, 31(6), 900-912.

Caldecott, B., Sartor, O., \& Spencer, T. (2017). Lessons from previous "Coal Transitions": High level summary for decision-makers, IDDRI and Climate Strategies, Paris.

Carattini, S., Baranzini, A., Thalmann, P., Varone, F., \& Vöhringer, F. (2017). Green taxes in a post-Paris world: Are millions of nays inevitable? Environmental and Resource Economics, 68(1), 97-128.

Coglianese, C., Finkel, A.M. and Carrigan, C. (Eds.) (2014). Does regulation kill jobs? Philadelphia: University of Pennsylvania Press.

Colantone, I., \& Stanig, P. (2017). The trade origins of economic nationalism: Import competition and voting behavior in Western Europe. American Journal of Political Science. Advance online publication. doi:10.1111/ajps.12358

Comin, D., \& Rode, J. (2013). From green users to green voters. NBER Working Paper 19219.

Cragg, M., Zhou, Y., Gurney, K., \& Kahn, M. (2013). Carbon geography: The political economy of congressional support for legislation intended to mitigate greenhouse gas production. Economic Inquiry, 51(2), 1640-1650.

Dechezleprêtre, A., \& Sato, M. (2017). The impacts of environmental regulations on competitiveness. Review of Environmental Economics and Policy, 11(2), 183-206.

Dinda, S. (2004). Environmental kuznets curve hypothesis: A survey. Ecological Economics, 49(4), 431-455.

Drews, S., \& Van den Bergh, J. C. (2016). What explains public support for climate policies? A review of empirical and experimental studies. Climate Policy, 16(7), 855-876.

The Economist. (2012). Jobs v Health, https://www.economist.com/node/21563964/print

Ekins, P., \& Speck, S. (1999). Competitiveness and exemptions from environmental taxes in Europe. Environmental and Resource Economics, 13(4), 369-396.

Fankhauser, S., Sehlleier, F., \& Stern, N. (2008). Climate change, innovation and jobs. Climate Policy, 8(4), $421-429$.

Galgóczi, B. (2014). The long and winding road from black to green. International Journal of Labour Research, 6(2), 217-240.

Greenstone, M. (2002). The impacts of environmental regulations on industrial activity: Evidence from the 1970 and 1977 clean air act amendments and the census of manufactures. Journal of Political Economy, 110(6), 1175-1219.

Hafstead, M. A., \& Williams, R. C. (2018). Unemployment and environmental regulation in general equilibrium. Journal of Public Economics, 160, 50-65.

Joltreau, E., \& Sommerfeld, K. (2018). Why does emissions trading under the EU emissions trading system (ETS) not affect firms' competitiveness? Empirical findings from the literature. Climate Policy. doi:10.1080/14693062.2018.1502145

Kahn, M., \& Kotchen, M. (2011). Business cycle effects on concern about climate change: The chilling effect of recession. Climate Change Economics, 2(03), 257-273.

Kahn, M., \& Mansur, E. (2013). Do local energy prices and regulation affect the geographic concentration of employment? Journal of Public Economics, 101, 105-114.

Le Blanc, A., \& Zwarterook, I. (2014). Industrial risk management shifting towards a more just transition. International Journal of Labour Research, 6(2), 131-152.

Lee, T., Markowitz, E., Howe, P., Ko, C., \& Leiserowitz, A. (2015). Predictors of public climate change awareness and risk perception around the world. Nature Climate Change, 5(11), 1014-1020.

Le Monde. (2018). Les centrales à charbon seront difficiles à fermer. Retrieved from https://www.lemonde.fr/economie/article/2018/ 07/09/les-centrales-a-charbon-seront-difficiles-a-fermer_5328318_3234.html

Marin, G., \& Vona, F. (2018). Climate policies and skill-biased employment dynamics: Evidence from EU countries, OFCE working paper.

Martin, R., Muûls, M., De Preux, L., \& Wagner, U. (2014). Industry compensation under relocation risk: A firm-level analysis of the EU emissions trading scheme. The American Economic Review, 104(8), 2482-2508.

Mathys, N. A., \& de Melo, J. (2011). Political economy aspects of climate change mitigation efforts. The World Economy, 34(11), 1938-1954.

Morgenstern, R. D., Pizer, W. A., \& Shih, J. S. (2002). Jobs versus the environment: An industry-level perspective. Journal of Environmental Economics and Management, 43(3), 412-436.

Mulatu, A., Gerlagh, R., Rigby, D., \& Wossink, A. (2010). Environmental regulation and industry location in Europe. Environmental and Resource Economics, 45(4), 459-479.

Nordhaus, W. (2015). Climate clubs: Overcoming free-riding in international climate policy. American Economic Review, 105(4), 1339-1370.

OECD. (2014). Environmental performance review: Sweden, Paris.

Olson, M. (1965). The logic of collective action: Public goods and the theory of groups. Cambridge, MA: Harvard University Press. 
Pascucci, P. (2014). La salvaguardia dell'occupazione nel decreto "salva Ilva". Diritto alla salute vs diritto al lavoro?. I Working papers di Olympus, (27).

Politico. (2016). Europe's last coal mines struggle for lifelines. Retrieved from https://www.politico.eu/article/europe-chokes-on-coal/

Pollitt, H., Alexandri, E., Chewpreecha, H., \& Klaassen, G. (2015). Macroeconomic analysis of the employment impacts of future EU climate policies. Climate Policy, 15(5), 604-625.

Rode, J., \& Weber, A. (2016). Does localized imitation drive technology adoption? A case study on rooftop photovoltaic systems in Germany. Journal of Environmental Economics and Management, 78, 38-48.

Rosemberg, A. (2010). Building a just transition: The linkages between climate change and employment. International Journal of Labour Research, 2(2), 125-161.

Rosés, J., \& Wolf, N. (2018). Regional economic development in Europe, 1900-2010: a description of the patterns, CEPR Discussion Paper No. 12749.

Scruggs, L., \& Benegal, S. (2012). Declining public concern about climate change: Can we blame the great recession? Global Environmental Change, 22(2), 505-515.

Smith, V. (2015). Should benefit-cost methods take account of high unemployment? Symposium introduction: Figure 1. Review of Environmental Economics and Policy, 9(2), 165-178.

Sovacool, B., Linnér, B., \& Goodsite, M. (2015). The political economy of climate adaptation. Nature Climate Change, 5(7), 616-618.

Stavins, R. N. (2003). Experience with market-based environmental policy instruments. In Handbook of environmental economics (Vol. 1 , pp. 355-435). North-Holland: Elsevier Science.

Sverker, C., Martinsson, J., and Matti, S. (2018): The impact of compensatory measures on public support for carbon taxation: An experimental study in Sweden. Climate Policy. doi:10.1080/14693062.2018.1470963

Taylor, R. (2015). A review of industrial restructuring in the ruhr valley and relevant points for China, Institute for industrial productivity working paper.

Thimm, K. (2010). Culture of Steel Germany's Ruhr Valley looks back to its future. Spiegel Online 05/03/2010.

Van der Ploeg, F. (2011). Natural resources: Curse or blessing? Journal of Economic Literature, 49(2), 366-420.

Vona, F, Marin, G., and Consoli, D. (2018b). Measures, drivers and effects of green employment: Evidence from US local labor markets, 2006-2014, Journal of Economic Geography. Forthcoming.

Vona, F., Marin, G., Consoli, D., and Popp, D. (2018a). Environmental regulation and green skills: An empirical exploration. Journal of the Association of Environmental and Resource Economists. Forthcoming.

Vona, F., \& Patriarca, F. (2011). Income inequality and the development of environmental technologies. Ecological Economics, 70(11), 2201-2213.

Walker, R. (2011). Environmental regulation and labor reallocation: Evidence from the clean Air Act. American Economic Review, 101(3), 442-447.

Walker, R. (2013). The transitional costs of sectoral reallocation: Evidence from the clean Air Act and the workforce. The Quarterly Journal of Economics, 128(4), 1787-1835.

Ward, H., \& Cao, X. (2012). Domestic and international influences on green taxation. Comparative Political Studies, 45(9), 1075-1103.

Wei, M., Patadia, S., \& Kammen, D. M. (2010). Putting renewables and energy efficiency to work: How many jobs can the clean energy industry generate in the US? Energy Policy, 38(2), 919-931.

Yamazaki, A. (2017). Jobs and climate policy: Evidence from British Columbia's revenue-neutral carbon tax. Journal of Environmental Economics and Management, 83, 197-216. 